\title{
INVESTMENT ANALYSIS ON CONSTRUCTION OF CONVENTION HALL IN SANGATTA OF KUTAI TIMUR REGENCY
}

\author{
Iskandar Irwan, Reseacher \\ Mulyadi Lalu, Wedyantaji Bambang, Lecturers \\ National Institute of Technology, Malang, East Java, Indonesia \\ *E-mail: iskandar dark@yahoo.co.id \\ ORCID: 0000-0002-7635-2331
}

\begin{abstract}
The objectives of this research are: 1) to analyze the way of calculating investment analysis, 2) to analyze the way of calculating the length of cooperation time with the investors of construction of Convention Hall in Sangatta of Kutai Timur Regency by using the cooperation system of Build-Operate-Transfer (BOT). This research applied the method of Payback Period (PP), Average Rate of Return (ARR), Discounted Cash Flow (DCF), calculation technique, Internal Rate of Return, and Net Present Value (NPV). Based on the calculation of investment analysis on the construction of Convention Hall in Sangatta of Kutai Timur Regency, the NPV is IDR $28,341,003,415$, the calculation of IRR $12.08 \%$ > the expected result rate $10 \%$. ARR calculation results obtained the ratio between the rate of net profit from this Convention Hall business has the investment age that is quite promising. In addition, based on the results of calculations, if $\mathrm{Net} b / c>1$, then the development activities to be carried out are feasible. The result of the calculation of Net b/c is 1.83 so that the construction of Convention Hall is feasible to carry on. Furthermore, after obtaining the ROI value, a company will have certainty and confidence that its business can continue and develop because its profit margin is worth $8.937 \%$ per year. The cooperation time with the investors of construction of the Convention Hall in Kutai Timur of East Borneo was carried out using the cooperation system of Build-Operate-Transfer (BOT) based on the calculation of cash flow (P/F, 10\%, n).
\end{abstract}

\section{KEY WORDS}

Investment, build-operate-transfer, convention hall, public service.

As a developing region, Kutai Timur Regency is actively conducting development programs in various sectors of life. Sangatta City, as the capital of Kutai Timur Regency, also has its own magnetic appeal for the people of Kutai Timur Regency to seek employment and hope. The magnitude of this accelerated development has an impact on the environmental structure throughout the Kutai Timur Regency. The Convention Hall is a building in Sangatta City of Kutai Timur Regency, which later will have a mixed used center concept consisting of Meeting Incentive, Convention and Exhibition (MICE) facilities plus a playground, cinema.

The management aspect of the Convention Hall in Sangatta City of Kutai Timur Regency is very important, including the stipulation of rental prices, because the revenue from this lease will return investment funds and will finance the operation of the Convention Hall in Sangatta City of Kutai Timur Regency as a whole. This research was conducted to determine the investment and management values by obtaining rental prices for space, both mall and space at the Convention Hall. To realize the construction of the Convention Hall in Sangatta City of Kutai Timur Regency that is sturdy and sustainable and integrated and dynamic, it needs to be planned appropriately. Thus, a long planning process in the field of guidance, development and construction has an orientation to face the future. It requires a consistent and sustainable direction, so that it does not oscillate in changing situations.

Looing at the limited quality of human resources, infrastructure targets, and inadequate budget support, the demand for policy formulation and the accuracy of the selection of programs arranged in the form of implementing the wheels of government and other fields must be able to answer the demands in all fields. Thus, the related institutions will have to 
develop aspects in all fields of cooperation and socialization between related agencies and institutions. Therefore, on the basis that a plan is a program that contains a detailed description of the planned work, then the plan must be made on a work plan that includes careful, efficient, effective and rational work descriptions that require teamwork (Azis, 2016).

Research Problems:

- How much are the investment in the construction of the Convention Hall that is appropriate to be built in Sangatta City of Kutai Timur Regency?

- When using the Build-Operate-Transfer (BOT) cooperation system, how long does it take to cooperate with the investors in the construction of the Convention Hall in Sangatta City of Kutai Timur Regency?

Research Objectives:

- Analyzing the way of calculating investment analysis in construction of the Convention Hall di in Sangatta City of Kutai Timur Regency;

- Analyzing the way of calculating the length of cooperation time with the investors of construction of convention hall in Sangatta of Kutai Timur Regency by using the cooperation system of Build-Operate-Transfer (BOT).

\section{METHODS OF RESEARCH}

Investment Analysis Instrument. Feasibility Analysis needs to examine matters relating to research instruments with financial aspects which include:

- Payback Period (PP). In this way, the value of money is considered not to shrink in the following years. If the amount of profit is already greater than the total cost incurred, when the payback period is still faster than the age of the project function (property), then the project is considered profitable (Lefley, 1996; Wong et.al., 2007; Mao, 1970);

- Average Rate of Return (ARR). The rate of net profit is the amount of net profit divided by the length of the project life or the average annual profit. In this calculation, the value of money is also considered to be not shrinking by the time. However, the calculation of the value of profits is still carried out during the life of the project. If the rate of profit gives a positive number, the project is profitable in which the greater the number means the more profitable it is (Easton, 2004; Goto \& Suzuki, 1989);

- Discounted Cash Flow (DCF). Discounting calculation techniques allow the assessment of projects with different ages and investments so that the pattern of costs and benefits over the life of the project is also different. Discounting makes it possible to determine what discount rate will be used in the calculation (Lundholm \& O'keefe, 2001; Fernandez, 2002);

- Internal Rate of Return. Calculation of IRR on an investment is carried out by bringing all the consequences that occur in the form of cash flow and then looking for an IRR (interest rate/ i) which equates to PV costs and PV benefits. After that, it is compared with MARR $\left(i{ }^{*}\right)$. If IRR (i)> MARR $\left(i{ }^{*}\right)$, then the investment is considered to be feasible (Hartman \& Schafrick, 2004);

- Net Present Value (NPV). The simplest criterion of the other criteria is to calculate the difference between the value of the current benefit flow and the current cost flow values of the project over the life of the project, at a certain interest rate (Shrieves \& Wachowicz, 2001).

$$
\text { NPV = PV Benefit }- \text { PV Cost }
$$

Decisions that can be made are: if NPV $>0$ means that the project can be profitable. Meanwhile, if NPV $<0$ then the project is not profitable.

Data Collection Technique. Data sources of feasibility analysis may come from secondary data sources, namely data relating to the Convention Hall building. Usually, the 
data obtained from documentation to explore data from secondary sources, namely data that already exists in the work of financial statement analysis of the Convention Hall building.

\section{RESULTS OF STUDY}

Investment Planning Data. To conduct the investment analysis of the Convention Hall building, the initial step taken is collecting data, both primary and secondary data. The following are the results of the data obtained by the authors. These data are obtained from the planning data of the Convention Hall building. Based on these data, it is expected to be used as a reference for calculating investment analysis in the Convention Hall building in Sangatta City, Kutai Timur Regency. Based on the drawing plan, the author obtains the following planning data:

Table 1 - Area of the Building

\begin{tabular}{|c|c|c|c|c|}
\hline No & Description & Size From The Picture & Unit From The Picture (F) & Area From The Picture (G) $\left(\mathrm{M}^{2}\right)$ \\
\hline 1 & 2 & 3 & 4 & $5=3^{*} 4$ \\
\hline 1 & Meeting Room & $10 \mathrm{~m} \times 12 \mathrm{~m}$ & 3 & 360 \\
\hline 2 & Stand & $3 \mathrm{~m} \times 4 \mathrm{~m}$ & 136 & 1.632 \\
\hline 3 & Rental Office & $5 \mathrm{~m} \times 12 \mathrm{~m}$ & 9 & 540 \\
\hline 4 & Convention Hall & $40 \mathrm{~m} \times 60 \mathrm{~m}$ & 1 & 2.400 \\
\hline 5 & Cafe & $10 \mathrm{~m} \times 15 \mathrm{~m}$ & 1 & 150 \\
\hline 6 & Internet Cafe & $7 \mathrm{~m} \times 11 \mathrm{~m}$ & 1 & 77 \\
\hline 7 & Coffee Shop & $10 \mathrm{~m} \times 11 \mathrm{~m}$ & 1 & 710 \\
\hline 8 & Store & $3 \mathrm{~m} \times 5 \mathrm{~m}$ & 48 & 252 \\
\hline 9 & Office & $7 \mathrm{~m} \times 9 \mathrm{~m}$ & 4 & 6.241 \\
\hline \multicolumn{7}{|c|}{ Total } \\
\hline
\end{tabular}

Based on the above table, the building consists of nine parts with a total area of $6,241 \mathrm{~m}^{2}$.

Cost Estimation Calculation. Investment costs are obtained from the Budget Plan for the construction of the Convention Hall in Sangatta City of Kutai Timur Regency. In addition to the Budget Plan, the authors estimated costs for several expenditure items that are predicted to be needed after the Convention Hall building is established. The following are the details of the investment costs for the Convention Hall building in Sangatta City of Kutai Timur Regency:

Table 2 - Investment Depreciation Costs

\begin{tabular}{|c|c|c|c|}
\hline No & Items & Cost & Description \\
\hline 1 & Land & $10,000,000,000$ & $\begin{array}{l}\text { price predictions for planned locations are taken from the } \\
\text { National Land Agency }\end{array}$ \\
\hline 2 & Construction 1 & $150,000,000,000$ & taken from the calculation of the budget plan \\
\hline 3 & Construction 2 & $75,000,000,000$ & taken from the calculation of the budget plan \\
\hline 4 & Public Facilities & $15,000,000,000$ & taken from the calculation of the budget plan \\
\hline 5 & $\begin{array}{l}\text { Water, Electricity, and Telephone } \\
\text { Installation }\end{array}$ & $1,500,000,000$ & taken from the budget plan \\
\hline 6 & Equipment & $500,000,000$ & taken from the budget plan \\
\hline 7 & Legalization & $150,000,000$ & $\begin{array}{c}\text { in accordance with government regulations regarding } \\
\text { Building Construction Permits }\end{array}$ \\
\hline \multirow[t]{2}{*}{8} & Transportation & $500,000,000$ & project requirements \\
\hline & Total of Construction & $252,650,000,000$ & \\
\hline 9 & Working Capital & $2,500,000,000$ & $\begin{array}{l}\text { capital issued before project implementation (preparatory } \\
\text { work) }\end{array}$ \\
\hline \multirow[t]{2}{*}{10} & Total of Working Capital & $2,500,000,000$ & \\
\hline & Total of Investment & $255,150,000,000$ & \\
\hline
\end{tabular}

Based on the above table, land, construction 1, construction 2, public facilities, water, electricity, and telephone installation and equipment items are obtained from the Budget Plan. Meanwhile, legalization is obtained in accordance with government regulations 
regarding Building Construction Permits. In addition, transportation and working capital are obtained from the authors' estimation. All investment costs above represent depreciated investment costs, whereas the investment costs that do not experience depreciation, can be calculated by assuming the total non-depreciation costs of IDR 2,500,000,000.

Feasibility Evaluation of the Investment Plan. Before analyzing the calculation using the Net Present Value Method (NPV), the calculation of the Net Cash Flow is conducted first by reducing the value of income each year with non-depreciating operational values. The calculation uses the help of the table below. The following are the steps used to do the calculation.

$$
V=S-T
$$

Where: V - Net Present Value (IDR); $\mathrm{S}$ - Income in the $\mathrm{n}$ year (IDR); $\mathrm{T}$ - Total NonDepreciation Operations (IDR) (formula notation uses the notation in the column).

Table 3 - Net Cash Flow

\begin{tabular}{|c|c|c|c|c|}
\hline \multirow{2}{*}{ No } & \multirow{2}{*}{ Year } & Income & Non-Depreciation Operations & Net Cash Flow \\
\cline { 3 - 5 } & & $\mathrm{S}$ & $\mathrm{T}$ & $\mathrm{V}=\mathrm{S}-\mathrm{T}$ \\
\hline 1 & 2 & 3 & 4 & $5=3-4$ \\
\hline 1 & 2017 & $28,206,076,000$ & - & $28,206,076,000$ \\
\hline 2 & 2018 & $31,960,304,716$ & $2,832,750,000$ & $29,127,554,716$ \\
\hline 3 & 2019 & $36,214,221,273$ & $3,209,789,025$ & $33,004,432,248$ \\
\hline 4 & 2020 & $41,034,334,125$ & $3,637,011,944$ & $37,397,322,180$ \\
\hline 5 & 2021 & $46,496,003,997$ & $4,121,098,234$ & $42,374,905,763$ \\
\hline 6 & 2022 & $52,684,622,129$ & $4,669,616,409$ & $48,015,005,720$ \\
\hline 7 & 2023 & $59,696,945,334$ & $5,291,142,353$ & $54,405,802,981$ \\
\hline 8 & 2024 & $67,642,608,758$ & $5,995,393,400$ & $61,647,215,358$ \\
\hline 9 & 2025 & $76,645,839,984$ & $6,793,380,262$ & $69,852,459,722$ \\
\hline 10 & 2026 & $86,847,401,285$ & $7,697,579,175$ & $79,149,822,111$ \\
\hline \multicolumn{2}{|c|}{ Total } & $527,428,357,600$ & $44,247,760,802$ & $483,180,596,798$ \\
\hline
\end{tabular}

After the Net Cash Flow value is obtained, then the calculation of the Net Present Value (NPV) can be performed. The simplest criterion of the other criteria is to calculate the difference between the value of the current benefit flow and the current cost flow values of the project over the life of the project, at a certain interest rate.

$$
\text { NPV }=\text { PV Benefit }- \text { PV Cost }
$$

Decisions that can be made are: if NPV $>0$ means that the project can be profitable. Meanwhile, if NPV $<0$ then the project is not profitable. The following steps are used to calculate the Net Present Value (NPV):

- Cash flow from the calculation in table 4.10 above is calculated by formula code $\mathrm{W}=\mathrm{T}$; where: $\mathrm{W}=\mathrm{T}$ is Total Non-Depreciation Operations (IDR) (formula notation uses the notation in the column);

- $\mathrm{P} / \mathrm{F}$ factor or interest factor is obtained from the interest table in technical economics books or obtained in the following ways: $P / F$ factor $=(1+i)-n$ with the $X$ symbol on the table;

- Calculating the value of PV. $Y=W \times X$; where: $Y$ - Net Present Value (PV) (IDR); W Total Non-Depreciation Operations (IDR); $\mathrm{X}$ - interest factor (formula notation uses the notation in the column).

More detailed calculations can be seen in Table 4 below.

Based on table 4 above, the value can be known after getting PV Benefit - PV Cost. By using a result rate of $10 \%$ and calculating the residual value at the end of the business convention hall, then the NPV analysis can be calculated. Based on Table 4.11 the results of the NPV convention hall business calculation obtain an NPV value of IDR 28,341,003,415 (NPV > 0). Thus, the business of this convention hall is feasible/ appropriate to run. 
Table 4 - Net Present Value

\begin{tabular}{|c|c|c|c|c|}
\hline \multirow{2}{*}{ No } & \multirow{2}{*}{ Year } & Cash Flow (IDR) & $\mathrm{P} / \mathrm{F} ; 0 \% ; n$ & $\mathrm{PV}$ IDR \\
\cline { 2 - 4 } & 2 & $\mathrm{~W}=\mathrm{T}$ & $\mathrm{X}$ & $\mathrm{Y}=\mathrm{W}^{*} \mathrm{X}$ \\
\hline 1 & 2016 & 3 & 1 & $5=3^{*} 4$ \\
\hline 1 & 2017 & $(255,150,000,000)$ & 0.9091 & $(255,150,000,000)$ \\
\hline 2 & 2018 & $28,206,076,000$ & 0.8264 & $25,641,887,273$ \\
\hline 3 & 2019 & $29,127,554,716$ & 0.7513 & $24,072,359,269$ \\
\hline 4 & 2020 & $33,004,432,248$ & 0.6830 & $24,796,718,443$ \\
\hline 5 & 2021 & $37,397,322,180$ & 0.6209 & $26,542,874,244$ \\
\hline 6 & 2022 & $42,374,905,763$ & 0.5645 & $27,103,218,980$ \\
\hline 7 & 2023 & $48,015,005,720$ & 0.5132 & $27,918,779,479$ \\
\hline 8 & 2024 & $54,405,802,981$ & 0.4665 & $28,758,880,934$ \\
\hline 9 & 2025 & $61,647,215,358$ & 0.4241 & $29,624,261,806$ \\
\hline 10 & 2026 & $69,852,459,722$ & 0.3855 & $30,515,682,774$ \\
\hline 11 & $79,149,822,111$ & 0.3855 & $13,204,857,663$ \\
\hline & Residual Value & $34,250,000,000$ & & $28,341,003,415$ \\
\hline
\end{tabular}

In this calculation way, the value of money is considered not to shrink in the following years. If the amount of profit is already greater than the total cost incurred, then the project is considered profitable.

$$
P B P=T_{p-1}+\frac{\sum_{i=1}^{n} \overline{I_{i}}-\sum_{i=1}^{n} \bar{B} i c p-1}{\bar{B} p}
$$

Where: $\mathrm{PBP}=$ Payback Period; $T_{P-1}=$ The years before $\mathrm{PBP} ; \overline{I_{i}}=$ The amount of investment that has been discounted; $\frac{}{B_{i c n-1}}=$ The amount of profit that has been discounted before PBP; $\frac{-}{B_{p}}=$ The amount of benefits in PBP.

Table 5 - Discounted Payback Period

\begin{tabular}{|c|c|c|c|c|c|}
\hline No & Year & Cash Flow (IDR) & P/F; $10 \% ; n$ & PV IDR & NPV IDR \\
\hline 1 & 2 & 3 & 4 & $5=3^{\star} 4$ & 6 \\
\hline 1 & 2016 & $(255,150,000,000)$ & 1 & $(255,150,000,000)$ & $(255,150,000,000)$ \\
\hline 2 & 2017 & $28,206,076,000$ & 0.9091 & $25,641,887,273$ & $(229,508,112,727)$ \\
\hline 3 & 2018 & $29,127,554,716$ & 0.8264 & $24,072,359,269$ & $(205,435,753,458)$ \\
\hline 4 & 2019 & $33,004,432,248$ & 0.7513 & $24,796,718,443$ & $(180,639,035,015)$ \\
\hline 5 & 2020 & $37,397,322,180$ & 0.6830 & $25,542,874,244$ & $(155,096,160,771)$ \\
\hline 6 & 2021 & $42,374,905,763$ & 0.6209 & $26,311,482,551$ & $(128,784,678,220)$ \\
\hline 7 & 2022 & $48,015,005,720$ & 0.5645 & $27,103,218,980$ & $(101,681,459,240)$ \\
\hline 8 & 2023 & $54,405,802,981$ & 0.5132 & $27,918,779,479$ & $(73,762,679,761)$ \\
\hline 9 & 2024 & $61,647,215,358$ & 0.4665 & $28,758,880,934$ & $(45,003,798,828)$ \\
\hline 10 & 2025 & $69,852,459,722$ & 0.4241 & $29,624,261,806$ & $(15,379,537,022)$ \\
\hline 11 & 2026 & $79,149,822,111$ & 0.3855 & $30,515,682,774$ & $15,136,145,752$ \\
\hline & Residual Value & $34,250,000,000$ & 0.3855 & $13,204,857,663$ & $28,341,003,415$ \\
\hline
\end{tabular}

Based on the calculation of cash flow (P/F, 10\%, n) in the NPV calculation table above, the Discounted Payback Period calculation can be performed. Based on the DPP calculation, the value of the Discounted Payback Period (DPP) from the business convention hall is 10 years; that is equal to the investment period. It explains that the business of the convention hall is feasible because the return of the initial capital of the business as evidenced by the value of the DPP is equal to the age of the planned project is $=9$ years 6.04 months.

Based on table 5 , the value of the payback period is positive at IDR $28,341,003,415$. In other words, the value of profits is greater than the amount spent. Thus, it can be concluded that the project is profitable and feasible to run. 
The way to calculate the IRR on an investment is to bring all the consequences that occur in the form of cash flow then proceed with finding the IRR (interest rate/ i) which equates to PV costs and PV benefits. After that, it is compared with MARR (i*). If IRR (i)> $\operatorname{MARR}\left(i^{*}\right)$, then the investment is said to be feasible. The following are the steps used in calculating the Internal Rate of Return (IRR) in this investment analysis which can be formulated as follows:

$$
\operatorname{IRR}=\mathrm{i} 1+\underline{\text { NPV } 1}(\mathrm{i} 1-\mathrm{i} 2)
$$

(NPV 1 - NPV 2)

Where: $\mathrm{i} 1$ = discount rate that produces NPV $1 ; \mathrm{i} 2$ = discount rate that produces NPV 2. The following table calculates the value of Internal Rate of Return.

Table 6 - Internal Rate of Return

\begin{tabular}{|c|c|c|c|c|c|c|}
\hline No & \multirow{2}{*}{ Year } & Cash Flow (IDR) & P/F; $0 \% ; n$ & \multirow{2}{*}{ PV IDR } & P/F; $0 \% ; n$ & \multirow{2}{*}{ PV IDR } \\
& 2 & $10 \%$ & & $13 \%$ & \\
\hline 1 & 3 & 4 & $5=3^{*} 4$ & 6 & $7=3^{*} 6$ \\
\hline 1 & 2016 & $(255,150,000,000)$ & 1 & $(255,150,000,000)$ & 1 & $(255,150,000,000)$ \\
\hline 2 & 2017 & $28,206,076,000$ & 0.9091 & $25,641,887,273$ & 0.8850 & $24,961,129,204$ \\
\hline 3 & 2018 & $29,127,554,716$ & 0.8264 & $24,072,359,269$ & 0.7831 & $22,811,147,870$ \\
\hline 4 & 2019 & $33,004,432,248$ & 0.7513 & $24,796,718,443$ & 0.6931 & $22,873,727,126$ \\
\hline 5 & 2020 & $37,397,322,180$ & 0.6830 & $25,542,874,244$ & 0.6133 & $22,936,478,058$ \\
\hline 6 & 2021 & $42,374,905,763$ & 0.6209 & $26,311,482,551$ & 0.5428 & $22,999,401,140$ \\
\hline 7 & 2022 & $48,015,005,720$ & 0.5645 & $27,103,218,980$ & 0.4803 & $23,062,496,842$ \\
\hline 8 & 2023 & $54,405,802,981$ & 0.5132 & $27,918,779,479$ & 0.4251 & $23,125,765,639$ \\
\hline 9 & 2024 & $61,647,215,358$ & 0.4665 & $28,758,880,934$ & 0.3762 & $23,189,208,005$ \\
\hline 10 & 2025 & $69,852,459,722$ & 0.4241 & $29,624,261,806$ & 0.3329 & $23,252,824,416$ \\
\hline 11 & 2026 & $79,149,822,111$ & 0.3855 & $30,515,682,774$ & 0.2946 & $23,316,615,350$ \\
\hline & Nilai Sisa & $34,25,000,000$ & 0.3855 & $13,204,857,663$ & 0.2946 & $10,089,650,923$ \\
\hline & \multicolumn{3}{|c|}{ NPV 1} & $28,341,003,415$ & NPV 2 & $(12,531,555,428)$ \\
\hline
\end{tabular}

Source: Analysis Results.

The calculation is carried out by trial and error, using the interpolation method where the result rate is increased to $13 \%$ to NPV $<0$.

The IRR value is $12.08 \%>$ the expected $10 \%$ of result rate, so the convention hall business is worthy of being established.

The calculation of Net B/C Ratio is performed by dividing the value of PV benefits by the value of $P V$ costs. If the value of $B / C>0$, then the project is feasible to run. The following is the calculation table of Net $B / C$ Ratio.

Table 7 - Net B/C Ratio

\begin{tabular}{|c|c|c|c|c|c|c|c|}
\hline NO & Years & Benefit & $\begin{array}{c}\mathrm{P} / \mathrm{F} ; 0 \% ; \mathrm{n} \\
10 \%\end{array}$ & PV IDR & Cost & $\frac{\mathrm{P} / \mathrm{F} ; 0 \% ; \mathrm{n}}{10 \%}$ & PV IDR \\
\hline 1 & 2 & 3 & 4 & $5=3^{*} 4$ & 6 & 7 & $8=6 * 7$ \\
\hline 1 & 2017 & $28,206,076,000$ & 0.5645 & $15,921,594,571$ & $24,340,000,000$ & 0.5645 & $13,739,295,458$ \\
\hline 2 & 2018 & $31,960,304,716$ & 0.5132 & $16,400,689,826$ & $24,672,750,000$ & 0.5132 & $12,661,021,962$ \\
\hline 3 & 2019 & $36,214,221,273$ & 0.4665 & $16,894,201,493$ & $25,049,789,025$ & 0.4665 & $11,685,911,453$ \\
\hline 4 & 2020 & $41,034,334,125$ & 0.4241 & $17,402,563,374$ & $25,477,011,944$ & 0.4241 & $10,804,740,089$ \\
\hline 5 & 2021 & $46,496,003,997$ & 0.3855 & $17,926,222,326$ & $25,961,098,234$ & 0.3855 & $10,009,127,210$ \\
\hline 6 & 2022 & $52,684,622,129$ & 0.3505 & $18,465,638,653$ & $26,509,616,409$ & 0.3505 & $9,291,458,829$ \\
\hline 7 & 2023 & $59,696,945,334$ & 0.3186 & $19,021,286,507$ & $27,131,142,353$ & 0.3186 & $8,644,818,073$ \\
\hline 8 & 2024 & $67,642,608,758$ & 0.2897 & $19,593,654,310$ & $27,835,393,400$ & 0.2897 & $8,062,921,964$ \\
\hline 9 & 2025 & $76,645,839,984$ & 0.2633 & 5,180 & $28,633,380,262$ & 0.2633 & $7,540,063,939$ \\
\hline \multirow[t]{2}{*}{10} & 2026 & $86,847,401,285$ & 0.2394 & $20,790,577,376$ & $29,537,579,175$ & 0.2394 & $7,071,061,612$ \\
\hline & & & Net Benefit & $182,599,673,615$ & & Net Cost & $99,510,420,589$ \\
\hline
\end{tabular}

Based on the above table, the net benefit value is IDR $182,599,673,615$ while the net cost value is IDR $99,510,420,589$. So, the $B / C$ value is: 


$$
B / C=\text { IDR 182,599,673,615 / IDR 99,510,420,589 = 1.835 > } 1
$$

The above calculation gets a $\mathrm{B} / \mathrm{C}$ value of $1,835>1$. So, it is concluded that the project is feasible to work on.

Return on Investment (ROI). Return on Investment (ROI) is a measurement of the company's overall ability that generates profits with the total assets available within the company. According to S. Munawir (2007: 89), Return on Investment (ROI) is a form of profitability ratios used to measure a company's ability to generate profits derived from overall funds on assets used for company operations.

The following is taken from Table 4.9 Cash Flow as follows:

$$
\begin{aligned}
& \text { Total Investment Value }=\operatorname{IDR} 255,150,000,000 \\
& \text { Net Cash Flow Amount }=\operatorname{IDR} 483,180,596,798
\end{aligned}
$$

So, according to S. Munawir (2007: 89), it is included in the formula as follows:

$$
\mathrm{ROI}=(\text { return on investment }- \text { initial investment }) / \text { investment } \times(100)=89.371 \%
$$

This obtained ROI value is for a period of 10 years, so to obtain the annual value, the calculation is as follows:

$$
\mathrm{ROI} / \text { Year }=8.937 \%
$$

By obtaining the ROI value, a company will have certainty and confidence that its business can continue and develop because its profit margin is worth $8.937 \%$ per year.

\section{CONCLUSION}

Based on the calculation of investment analysis on the construction of Convention Hall in Sangatta of Kutai Timur Regency, the NPV is IDR 28,341,003,415, the calculation of IRR $12.08 \%>$ the expected result rate $10 \%$. ARR calculation results obtained the ratio between the rate of net profit from this Convention Hall business has the investment age that is quite promising because it obtains positive value of IDR 26,228,059,679.8. In addition, based on the results of calculations, if $\mathrm{Net} b / c>1$, then the development activities to be carried out are feasible. The result of the calculation of $\mathrm{Net} b / \mathrm{c}$ is 1.83 so that the construction of Convention Hall is feasible to carry on. Furthermore, after obtaining the ROI value, a company will have certainty and confidence that its business can continue and develop because its profit margin is worth $8.937 \%$ per year.

The cooperation time with the investors of construction of the Convention Hall in Kutai Timur of East Borneo was carried out using the cooperation system of Build-OperateTransfer (BOT) based on the calculation of cash flow (P/F, 10\%, n). Based on NPV calculations, Discounted Payback Period calculations can be performed. Based on the DPP calculation, the value of the Discounted Payback Period (DPP) of the convention hall business is 10 years which is the same as the investment period. This explains that the business of the convention hall is feasible to run, because the return of the initial capital of the business as evidenced by the value of the DPP is the same as the planned project age of 9 years 6.04 months.

\section{REFERENCES}

1. Azis, S. (2016). Economic Feasibility Analysis of Semantok Dam at Nganjuk Indonesia, Australian Journal of Basic and Applied Sciences, 10(14), 207-216.

2. Easton, P. D. (2004). PE ratios, PEG ratios, and estimating the implied expected rate of return on equity capital. The accounting review, 79(1), 73-95. 
3. Fernandez, P. (2002). Three residual income valuation methods and discounted cash flow valuation. SSRN WP, 296945.

4. Goto, A., \& Suzuki, K. (1989). R \& D capital, rate of return on R \& D investment and spillover of $R \& D$ in Japanese manufacturing industries. The Review of Economics and Statistics, 555-564.

5. Hartman, J. C., \& Schafrick, I. C. (2004). The relevant internal rate of return. The Engineering Economist, 49(2), 139-158.

6. Lefley, F. (1996). The payback method of investment appraisal: a review and synthesis. International Journal of Production Economics, 44(3), 207-224.

7. Lundholm, R., \& O'keefe, T. (2001). Reconciling value estimates from the discounted cash flow model and the residual income model. Contemporary Accounting Research, 18(2), 311-335.

8. Mao, J. C. (1970). Survey of capital budgeting: Theory and practice. The Journal of Finance, 25(2), 349-360.

9. Shrieves, R. E., \& Wachowicz Jr, J. M. (2001). Free Cash Flow (FCF), Economic Value Added (EVA ${ }^{\mathrm{TM}}$ ), and Net Present Value (NPV): A Reconciliation of Variations of Discounted-Cash-Flow (DCF) Valuation. The engineering economist, 46(1), 33-52.

10. Wong, I. L., Eames, P. C., \& Perera, R. S. (2007). A review of transparent insulation systems and the evaluation of payback period for building applications. Solar Energy, 81(9), 1058-1071. 